\title{
PREPARATION AND INTEGRITY EXAMINATION OF FREEZE DRIED KIT OF TRASTUZUMAB-IMMUNOCONJUGATES AND COLD LABELED IMMUNOCONJUGATES BY APPLYING SDS-PAGE ELECTROPHORESIS
}

\author{
Marija Sterjova ${ }^{1,2}$, Predrag Džodić2 , Tatjana Ruskovska ${ }^{1}$, Paulina Apostolova ${ }^{1}$, \\ Milan Risteski ${ }^{3}$, Emilija Janevik-Ivanovska ${ }^{1}$
}

\begin{abstract}
Radioimmunoconjugates are promising agents in diagnostics and treatment of different types of cancers. The aim of this study was the formulation of stable freeze dried kits of trastuzumab with three types of bifunctional chelators for further radiolabeling. The integrity of the antibody in formulated conjugates was examinated with sodium dodecyl sulfate polyacrylamide gel electrophoresis (SDS-PAGE).

Trastuzumab is a humanized monoclonal antibody used in the therapy of aggressive HER2 positive breast cancer. Conjugation of trastuzumab was made with various chelators: $p$ SCN-Bn-DTPA (1:10; 1:20; 1:50), p-SCN-Bn-DOTA (1:20), and 1B4M-DTPA (1:10; 1:20; $1: 50)$. The purified immunoconjugates were lyophilized by applying two day protocol in order to produce the stable freeze dried kits. Cold labeling with nonradioactive isotopes $\mathrm{LuCl}_{3}$ and $\mathrm{YCl}_{3}$ was performed to examine the possible modifications of secondary structure after radioactive labeling. SDS-PAGE electrophoresis was used to estimate the purity and integrity of the antibody before and after conjugations, lyophilization and labeling under reducing conditions.

The obtained results show that there is no degradation of the examined antibody. The trastuzumab-conjugates and cold labeled formulations migrated in two bands ( $\sim 50 \mathrm{kDa}$ and $\sim 25 \mathrm{kDa})$, in the same way as IgG1 antibodies and unmodified trastuzumab.
\end{abstract}

Acta Medica Medianae 2019;58(3):15-23.

Key words: Bifunctional chelators, conjugations, electrophoresis, trastuzumab

\author{
${ }^{1}$ University "Goce Delčev", Faculty of Medical Sciences, Štip, RN \\ Macedonia \\ 2University of Niš, Faculty of Medicine, Department of \\ Pharmacy, Niš, Serbia \\ ${ }^{3}$ University Clinic of Radiotherapy and Oncology, Skopje, RN \\ Macedonia
}

Contact: Marija Sterjova

Sutjeska 43b/5, Štip, RN Macedonia

E-mail: marija.sterjova@ugd.edu.mk

\section{Introduction}

The human epidermal growth factor receptor (HER2) is overexpressed on a surface of the cells in aggressive breast cancer. HER2 positive breast cancers without anti-HER2 therapy lead to metastasis and very low survival rates of the patients (1). Trastuzumab is the first approved humanized monoclonal antibody. It's a potent anti-HER2 antibody which originates from murine 4D5 antibody (2). Carter et al., 1992 (3) cloned hypervariable regions from 4D5 in plasmids which are encoding formation of constant regions from human $I g G 1$ antibody. A vector that is encoding formation of chimeric antibody, which is additionally humanized, was successfully generated. Trastuzumab is binding to the IV subdomain of the receptor and manifests the effect through antibodydependent cellular cytotoxicity (4).

Conjugated antibodies provide high expectation for development of cancer-specific cytotoxic reagents. Each immunoconjugate has an enhanced therapeutic specificity due to the conjugation with antibody which shows specificity to a particular antigen on the surface of tumor cells (5). Radioimmunoconjugates are step forward in diagnostic and treatment of different types of cancers (6). Until now, there is no FDA registration of trastuzumab-radioimmunoconjugates for commercial use. A series of clinical and preclinical trials of radioimmunoconjugates for treatment and imaging of breast cancer with different radionuclides ${ }^{111} \mathrm{In}(7-9),{ }^{99} \mathrm{mTc}(10),{ }^{67} \mathrm{Ga}(11),{ }^{90} \mathrm{Y}$, ${ }^{86} Y(12),{ }^{177} \mathrm{Lu}(13,14)$ have been made in the past few years. Creation of stable immunocon-jugate with bifunctional chelators (BFCAs) is required in order to obtain succsessful labeling. This chelator allows binding to the antibody on the one side and coordinative binding of radioisotopes on the opposite. The commonly investigated chelators are: DOTA $(1,4,7,10$-tetraazacyclododecane-1,4,7,10-tetraacetic acid), DTPA (diethylene triamine pentaacetic acid), 
DTPA derivate 1B4M-DTPA (2-(4-isothi-ocyanatobenzyl)-6-methyl-diethylene-triaminepenta-acetic acid) and EDTA (ethylenediamine tetraacetic acid) (15). Due to the easy chemical and physical degradations, monoclonal antibodies are not stable in water solutions. The commonly processes of preparations are denaturation, deamidation, oxidation, deglycolisation, aggregation, precipitation and adsorption. In order to prolong the life of protein pharmaceuticals, it is necessary to remove the water from the product. The commonly used method is lyophilization which obtains stable freeze dried kits (16).

Examinations with non-radioactive isotopes ( $\mathrm{Lu}$ and $Y$ ) are done with intention to confirm that there are no changes in the secondary structure of the antibody after coordinative binding of the metal, because these studies are impossible with radioactive isotopes (17). Reducing sodium dodecyl sulfate polyacrylamide gel electrophoresis (SDS-PAGE) is important for the determination of molecular mass (Mr) as well as the possible degradations of trastuzumab, trastuzumab-immunoconjugates and cold labeled kits too (18).

The aim of this study was formulation of stable freeze dried kit of trastuzumab with $\mathrm{p}-\mathrm{SCN}-\mathrm{Bn}$ DOTA (2-(4-izothiocyanatobenzyl)-1,4,7,10-tetraazacyclododecane-1,4,7,10-tetraacetic acid), p-SCN-Bn1B4M-DTPA (2-(4-isothiocyanatobenzyl)-6-methyldiethylene-triaminepentaacetic acid) and p-SCN-BnDTPA (2-(4-izothiocyanatobenzyl)-diethylenetriaminepentaacetic acid) and subsequently labeling with cold isotopes ( $\mathrm{Lu}$ and $\mathrm{Y}$ ). Protein integrity determination and possible aggregations were investigated by using reducing one-dimensional SDS-PAGE.

\section{Material and methods}

Purification of trastuzumab. Trastuzumab was purified from Herceptin ${ }^{\circledR}$ (Hoffmann-La Roche, Basel, Switzerland) with Amicon ${ }^{\circledR}$ Ultra-4 (Sigma Aldrich,
Missouri, USA), $30 \mathrm{KDa}$ for ultrafiltration for 1 hour at $5000 \mathrm{rpm}$, by washing the antibody in six cycles with 0.1 M PBS, $\mathrm{pH}=8$, using HuMax 4k (Human, Wiesbaden, Germany) centrifuge.

Conjugation of trastuzumab. The conjugations were made by mixing the antibody with $10 \mathrm{mg} / \mathrm{mL}$ solution of BFCAs in different molar ratio ( $\mathrm{p}-\mathrm{SCN}-\mathrm{Bn}$ DTPA - $1: 10 ; 1: 20 ; 1: 50,1 B 4 M-D T P A ~-~ 1: 10 ; 1: 20$; $1: 50$ and $\mathrm{p}-\mathrm{SCN}-\mathrm{Bn}-\mathrm{DOTA}$ - 1:20) and 18 hours incubation on $4{ }^{\circ} \mathrm{C}$ with gentle shaking. The immunoconjugates were purified with six cycles of ultrafiltration (Amicon ${ }^{\circledR}$ Ultra-4, $30 \mathrm{KDa}$ ), by rinsing with $0.05 \mathrm{M}$ ammonium acetate, $\mathrm{pH}=7$. The concentration was adjusted to $1 \mathrm{mg} / \mathrm{mL}$ using the 6715 UV/Vis Spectrophotometer Jenway ${ }^{\circledR}$ (Stafford-shire, UK).

Lyophilization of trastuzumab-immunoconjugates. The volume of $1 \mathrm{~mL}$ of the solution was transferred to type I glass vials and lyophilized to solid state. The immunoconjugates were lyophilized with cryoprotectant and bulking agent, $1 \%$ mannitol $(50 \mu \mathrm{L}$ in each vial). The lyophilization was performed with Labconco Free Zone Stoppering Tray Dryer (Kansas City, Missouri, USA), using the protocol by Gjorgieva Ackova et al., 2014 (19), with several modifications. The samples were equally placed on the shelves after reaching the temperature of $4^{\circ} \mathrm{C}$. The first step was freezing the samples. The temperature was decreased at $-40^{\circ} \mathrm{C}, 1^{\circ} \mathrm{C} / \mathrm{min}$ (rate of cooling, from $4^{\circ} \mathrm{C}$ to $-40^{\circ} \mathrm{C}$ ) and the time of keeping was 5 hours. The second phase of preparation was primary drying at the temperature of $-10^{\circ} \mathrm{C}, 0.15^{\circ} \mathrm{C} / \mathrm{min}$ (rate of heating, from $-40{ }^{\circ} \mathrm{C}$ to $-25^{\circ} \mathrm{C}$ ) for 28 hours and pressure of $0.133 \mathrm{mBar}$. The third part was secondary drying on $25^{\circ} \mathrm{C}, 0.2^{\circ} \mathrm{C} / \mathrm{min}$ (rate of heating, from $-25^{\circ} \mathrm{C}$ to $25^{\circ} \mathrm{C}$ ) for 14 hours. The whole protocol of lyophilization is shown in Figure 1. After completing freeze drying, the vials were closed and kept at $4{ }^{\circ} \mathrm{C}$ in order to perform the following examinations.

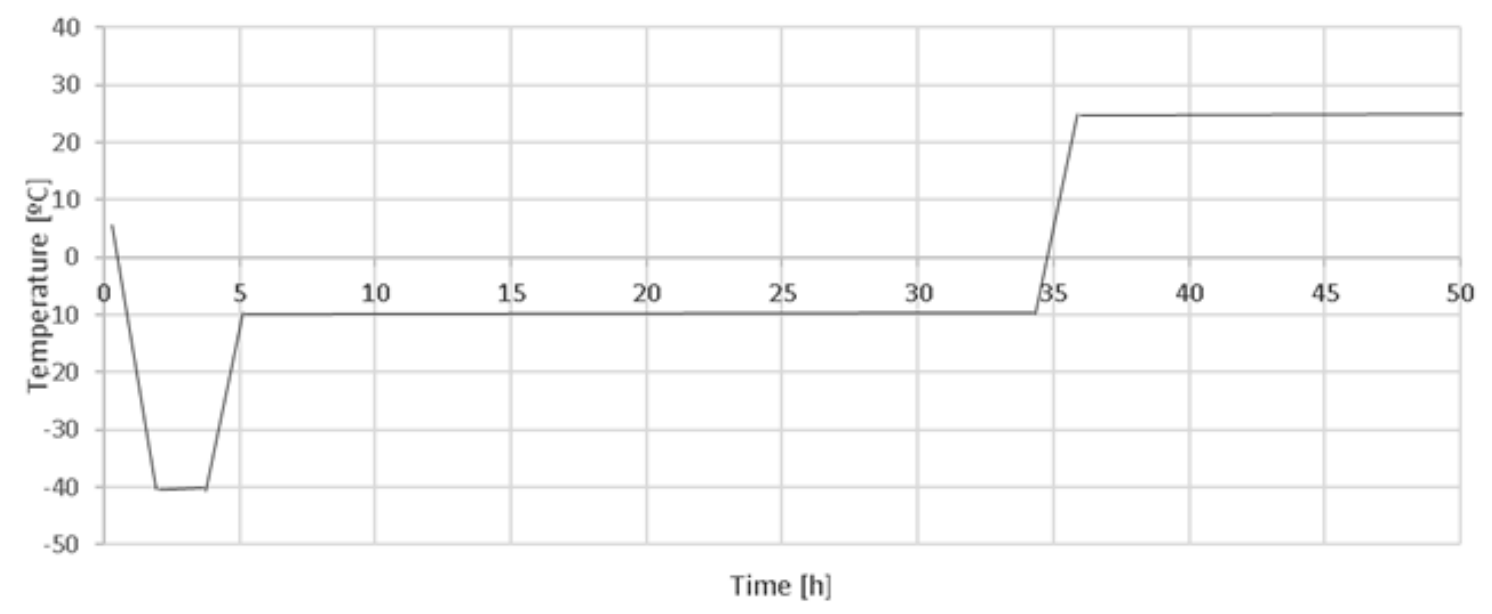

Figure 1. Lyophilization protocol 
Labeling trastuzumab-immunoconjugates with non-radioactive $L u$ and $Y$

The solutions of non-radioactive Lu and $\mathrm{Y}$ were prepared by dissolving of $\mathrm{LuCl}_{3}$ to concentration of $1.0709 \mu \mathrm{g} / \mu \mathrm{L}$ (equivalent to maximum tolerated dose (MTD) of ${ }^{177} \mathrm{Lu}(4377,1 \mathrm{MBq})$ ) and $\mathrm{YCl}_{3}$ to concentration of $1.1555 \mathrm{mg} / \mu \mathrm{L}$ (equivalent to MTD of ${ }^{90} \mathrm{Y}$ $(1049,69 \mathrm{MBq}))$. The immunoconjugates were dissolved with sterile $0.9 \%$ solution of $\mathrm{NaCl}$ and then labeled with $1 \mu \mathrm{L}$ of prepared solution of cold Lu and $Y$ to total volume of $1 \mathrm{~mL}$. The labeled DTPA and 1B4M-DTPA conjugates were incu-bated for $30 \mathrm{~min}$ at $25^{\circ} \mathrm{C}$ as well as DOTA conjugates were incubated for 1 hour at $40^{\circ} \mathrm{C}$.

Integrity examinations with sodium dodecyl sulphate polyacrylamide gel electrophoresis (SDSPAGE)

Gel electrophoresis was performed under reducing conditions with Enduro ${ }^{\circledR}$ Modular Vertical Gel Electrophoresis System (Labnet, Edison, NJ, USA), using mercaptoethanol. In this process, $12 \%$ separating acrylamide/bisacrylamide gel and $4 \%$ stacking gel was prepared according to the protocol of the manufacturer manual instructions. Electrophoresis was performed three times, under the same conditions. Concentration of each sample was $1 \mathrm{mg} / \mathrm{mL}$. At the first gel, unmodified trastuzumab and freeze dried immunoconjugates were applied after reconstitution with $0.9 \% \mathrm{NaCl}$. At the second and the third gel, immunoconjugates were applied labeled with non-radioactive Lu and Y. A mass of $30 \mu \mathrm{g}$ of sample was added in $10 \mu \mathrm{L}$ of loading buffer. Then the mixtures were heated for $5 \mathrm{~min}$ at dry bath at $98.5^{\circ} \mathrm{C}$ and centrifuged for $5 \mathrm{~min}$ at $5000 \mathrm{rpm}$. $25 \mu \mathrm{L}$ of each sample and $10 \mu \mathrm{L}$ of SigmaMarkerTM, Wide Range, Molecular Weight (Saint Louis, MO, USA) were applied in wells of stacking gel. According to our previous studies, constant voltage at $150 \mathrm{~V}$ and approximately current at $23 \mathrm{~mA}$ has been used as optimum condition. After finishing the entire process (which lasted approximately an hour and a half), the gel was placed for Coomassie staining for 20 hours. Discoloration was observed in the solution composed of water, methanol and acetic acid for 7-8 hours. All used reagents were from Sigma-Aldrich (Missouri, USA). The prepared gels were scanned with Glite 900 BW Gel Scanner (PacificImage, Torrance, CA).

\section{Results}

Stable freeze dried kits of trastuzumab-immunoconjugates were formulated. The structures of used BFCAs are shown in Figure 2. There are various groups (anhydride, bromoacetamid, isothiocyanate) that can be attached to the BFCAs molecules, to achieve an easier conjugation (17). The chelators have 4-izothiocyanatobenzyl groups in theirs structures which participate in the process of binding to the antibody (Figure 3). Thiourea linkage is created due to reaction between amino groups of lysine residues of trastuzumab and isothiocyanate groups of chelators (20). To remove the water and increase the stability, the immunoconjugates were lyophilized using the previously described protocol. The whole process included freezing of the sample and then removing the water by sublimation in a vacuum environment. After performing the freeze drying process solid formulations with a homogeneous structure were obtained. For further examinations, the stable freeze dried cakes were used. The integrity of the protein, purity and possible formation of aggregates after lyophilization and after cold labeling were established with SDS-PAGE. For comparison, unmodified trastuzumab in a concentration of $1 \mathrm{mg} / \mathrm{mL}$ was used. The electrophoresis was performed under reducing conditions. Disulfide bonds were reduced with 2-mercaptoethanol and antibody was separated in two fragments: two heavy chains $\sim 50 \mathrm{kDa}$ and two light chains $\sim 25 \mathrm{kDa}$ (Figure 4) (21). The gel with unmodified trastuzumab and trastuzumab-immunoconjugates with different molar ratio of BFCAs is shown in Figure 5 . The gels with cold labeled immunoconjugates are shown in Figure 6 and Figure 7, as well.

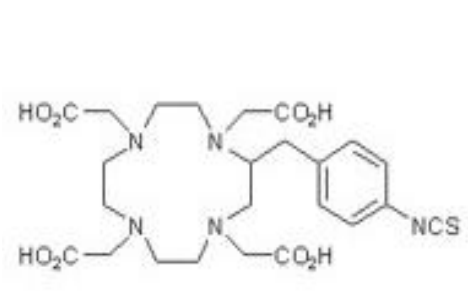

P-SCN-Bn-DOTA

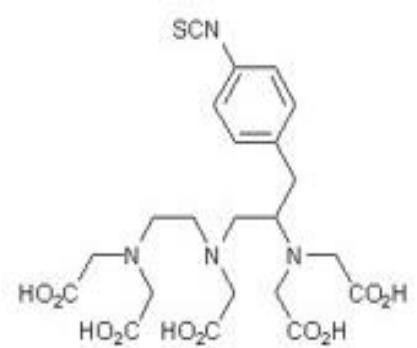

p-SCN-Bn-DTPA

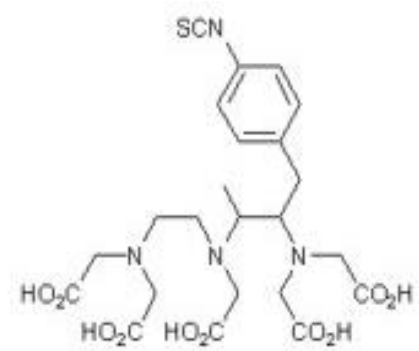

p-SCN-Bn-1B4M-DTPA

Figure 2. Structure of BFCAs 


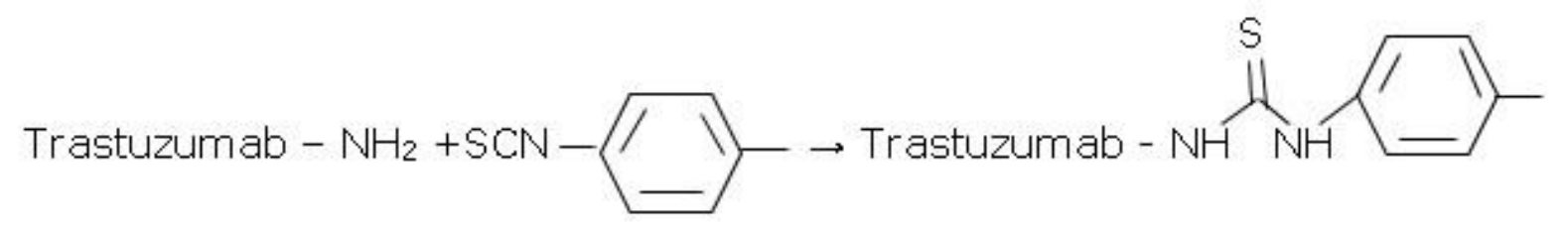

Figure 3. Reaction of conjugation

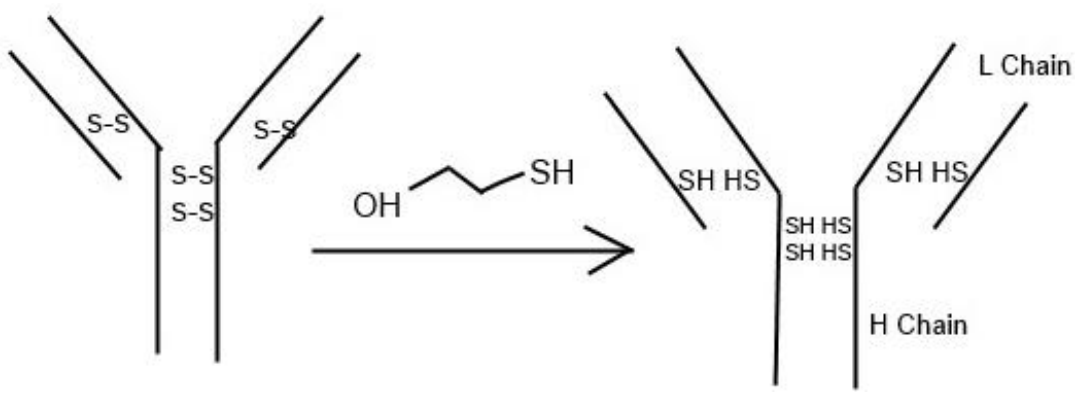

Figure 4. Reducing SDS-PAGE

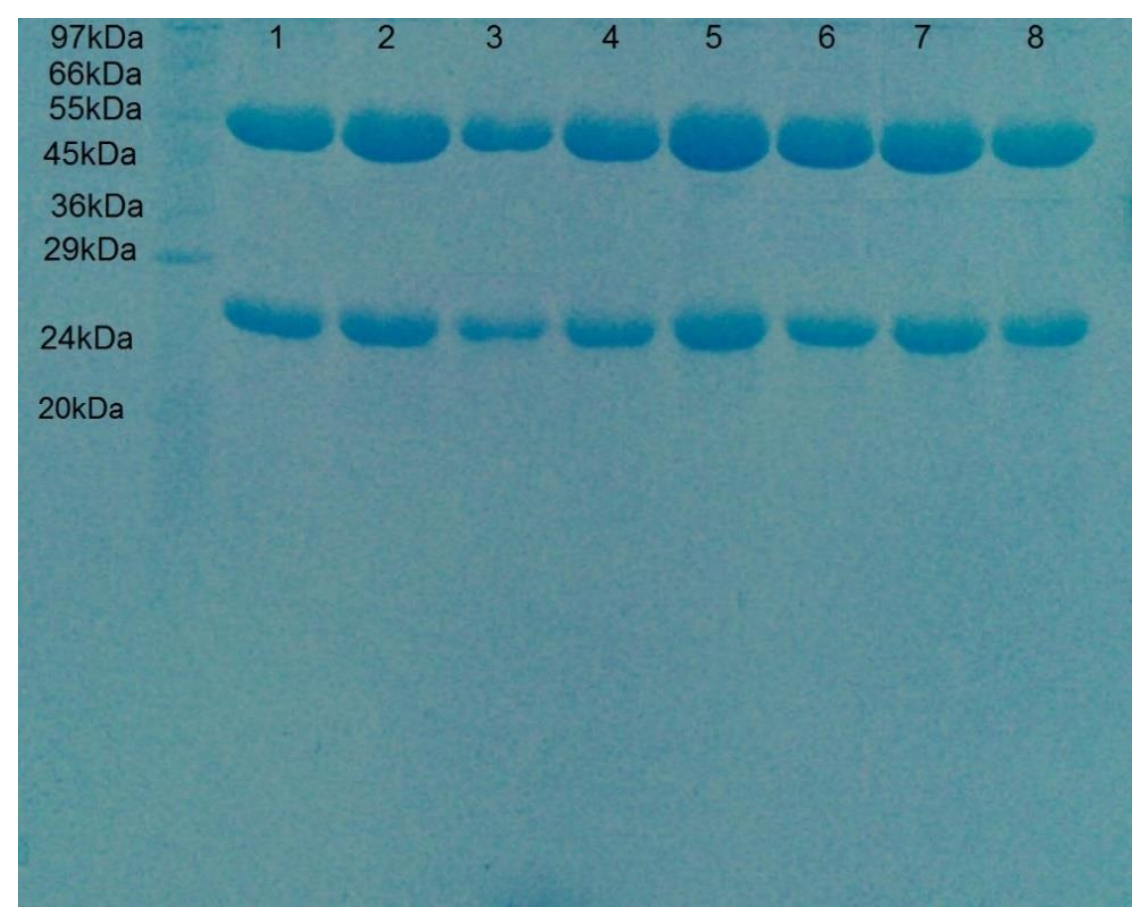

Figure 5. Reducing SDS-PAGE of Trastuzumab $1 \mathrm{mg} / \mathrm{mL}$ (1);

DTPA-Trastuzumab (1:10) (2); DTPA-Trastuzumab (1:20) (3);

DTPA-Trastuzumab (1:50) (4);

DOTA-Trastuzumab (1:20) (5);

1B4M-DTPA-Trastuzumab (1:10) (6);

1B4M-DTPA-Trastuzumab (1:20) (7);

1B4M-DTPA-Trastuzumab (1:50) (8). 


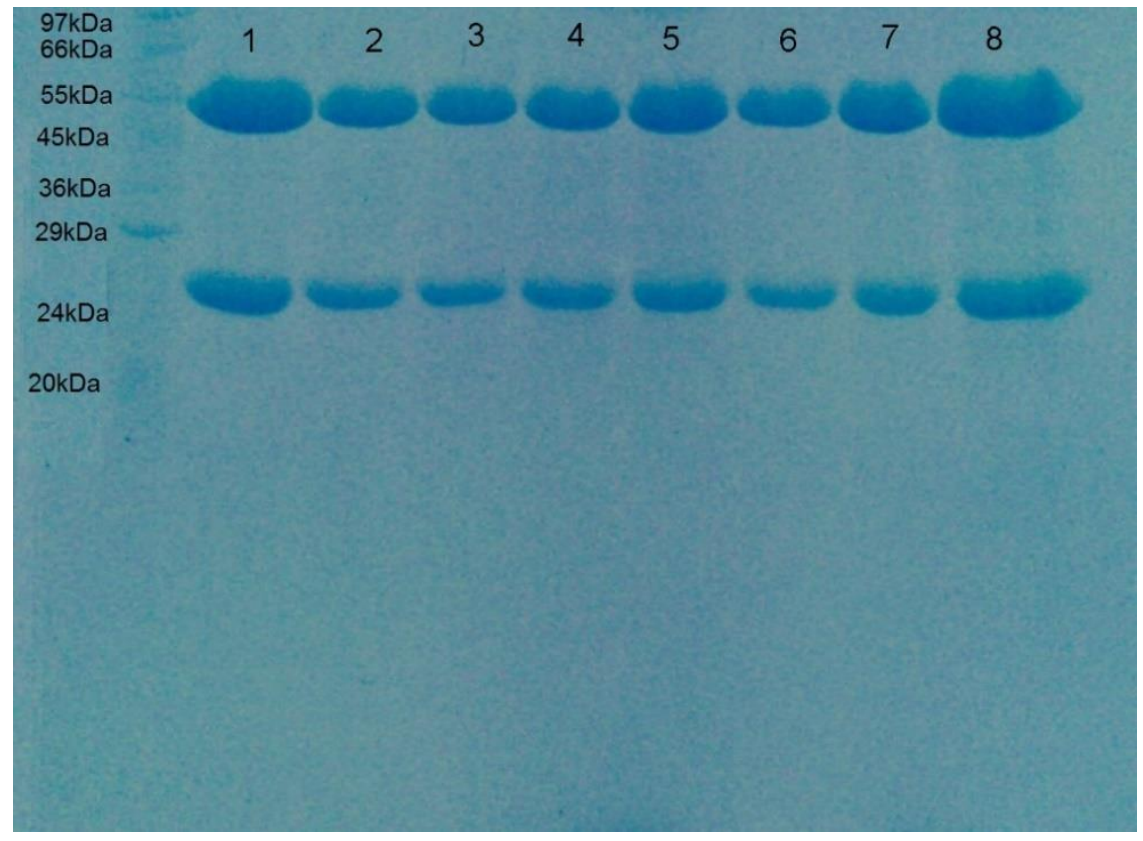

Figure 6. Reducing SDS-PAGE of Y-DTPA-Trastuzumab (1:10) (1); Lu-DTPA-Trastuzumab (1:10) (2);

Y-DTPA-Trastuzumab (1:20) (3);

Lu-DTPA-Trastuzumab (1:20) (4);

Y-DTPA-Trastuzumab (1:50) (5);

Y-DTPA-Trastuzumab (1:50) (6);

Y-DOTA-Trastuzumab (1:20) (7);

Lu-DOTA-Trastuzumab (1:20) (8).

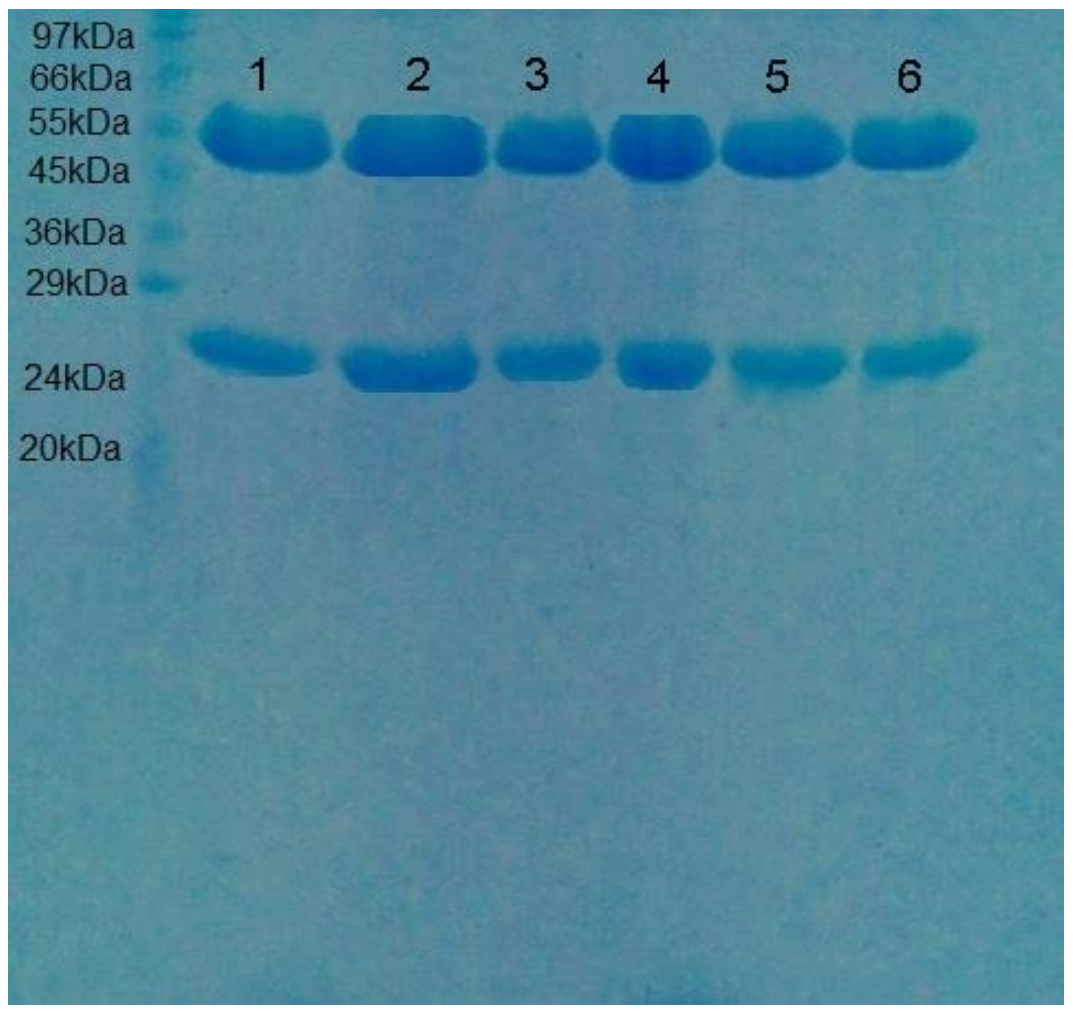

Figure 7. Reducing SDS-PAGE of Y-1B4M-DTPA-Trastuzumab (1:10) (1); Lu-1B4M-DTPA-Trastuzumab (1:10) (2);

Y-1B4M-DTPA-Trastuzumab (1:20) (3);

Lu-1B4M-DTPA-Trastuzumab $(1: 20)(4)$;

Y-1B4M-DTPA-Trastuzumab (1:50) (5);

Lu-1B4M-DTPA-Trastuzumab (1:50) (6). 


\section{Discussion}

Lyophilization has a major significance in the process of formulation of stable pharmaceutical products (vaccines, monoclonal antibodies and protein formulation). Properly selected conditions are essential for complete removal of water and retention of the structural integrity of the proteins. They are necessary procedures for obtaining stable, homogeneous cakes with flat surfaces which retain the properties after reconstitution. The first step, freezing, is important to the process of separation of the water from the solution and leads the protein to crystalline state, which is more stable. Control of crystallization and size of crystals during the freezing are critical parameters and the appropriate selection of cooling rate is very important. It is already known that slow cooling provides larger crystals, while faster freezing provides smaller crystals. On the other side, the faster cooling can lead to aggregations and denaturation of the antibody. During preparation of aqueous formulations, it is necessary to place them on the cooled shelves to $4-5{ }^{\circ} \mathrm{C}$ (22). With an intention to improve the crystallization, the annealing step is often included (23). Our research team has already some experience with freeze drying of monoclonal antibody rituximab. Namely, Gjorgieva Ackova et al., 2014 (19) used a three day protocol with included annealing process. The obtained results were promising, since stable cakes with no aggregates and denaturation of the antibody were produced. But, our goal was to shorten the length of procedures in two days with exclusion of the annealing step. Also, we tried to show that with the application of cooling rate of $1 \circ \mathrm{C} / \mathrm{min}$ we could obtain cakes with the same quality. The choice of the mentioned cooling rate was done based on results of the study of Tang and Pikal, 2004 (24). Our improvement of procedure of a super cooling without phase of separation and a uniform of ice structure was reached with the same rate of freezing.

The primary drying is the second step of lyophilization when the majority of frozen bulk water is removed by sublimation in a vacuum environment. Instead of 25 hours, the time was prolonged to 28 hours. Also, the secondary drying time was extended to 14 hours. At this phase some bound unfrozen water is removed at temperatures higher than $25^{\circ} \mathrm{C}$ (23). Many sugars (glucose, mannitol or trehalose) can be used like cryoprotectants, to protect the proteins from denaturation and inactivation during the process of freezing (25). Nounou et al., 2005 (26) have shown in their study that obtained freeze dried cakes without any cryoprotectant possessed a compact structure but also demonstrated difficulties in process of reconstitution. This is probably the result of using sugars as bulking agents in production of fluffy cakes for easy reconstruction. In our studies to protect the antibody from stress temperature and to obtain elegant cakes for easy reconstitution $1 \%$ mannitol was used. After the dissolving of the cakes with $0.9 \% \mathrm{NaCl}$ for less than a minute, clear to opalescent solutions were obtained without presence of visible solid particles and colloids.

The processes of conjugation and freeze drying of the antibodies can lead to changes in protein 20 integrity (aggregations and fragmentations). It is important to show that after cold labeling with $Y$ and $\mathrm{Lu}$, the metal does not change the structure of antibody. One of the most important methods for examination of protein integrity and purity is SDS-PAGE in reducing conditions (size-based method, where separation is based on the size of the molecules) (17, 27). Many stability studies of trastuzumab were made using a SDS-PAGE in reducing or non-reducing conditions. Under reducing conditions, trastuzumab was migrated as two bands a $\sim 50 \mathrm{kDa}$ and $\sim 25 \mathrm{kDa}$ (Mr of heavy and light chain), while under non-reducing conditions only one band at $\sim 150 \mathrm{kDa}$ was observed ( $\mathrm{Mr}$ of whole antibody) (18, 28, 29). Our group has already used the applied method of reducing electrophoresis for integrity examinations of rituximab after conjugation and lyophilization (17, 19).

Almost the same conditions were used for exammination of trastuzumab, with several modifications. In order to achieve reducing conditions, instead of dithiothreitol, 2-mercaptoethanol was used. The SDS -PAGE examinations were performed after six months storage of the freeze dried kits at the temperature of $4^{\circ} \mathrm{C}$. The cold labeling was done before starting the process of electrophoresis. The obtained results of migration of formed samples correspond to already published results for other IgG1 monoclonal antibodies $(18,28)$. Under reducing conditions, migration of the trastuzumab provided separation of two bands of fragments with molecular weight of $25 \mathrm{kDa}$ for light chain and $50 \mathrm{kDa}$ for heavy chain, proven with the Wide Range, molecular weight marker. The same intensity of the fragments of lyophilized and labeled conjugates with the fragments of pure commercial (unmodified) trastuzumab indicated that there was no degradation of the antibody. The results have shown that the conjugation, lyophilization and label-ing were successful, without any damage to the anti-body, with absence of fragmentation, denaturation and aggregation of the trastuzumab.

\section{Conclusion}

The results of electrophoretic examination have shown that stable freeze dried conjugates of trastuzumab were formulated with BFCAs in different molar ratios. The integrity and purity of the antibody were retained after cold labeling with $Y$ and Lu. Therefore, these kits will be used for further characterization of the secondary structure of the antibody and determination of the number of the chelators with Infra Infrared Spectroscopy (IR), Raman Spectroscopy and Matrix Assisted Laser Desorption Ionization Time of Flight Mass Spectrometer (MALDITOF-MS). Moreover, immunoconjugates are good basis for radiolabeling with application of ${ }^{177} \mathrm{Lu}$ and ${ }^{90} \mathrm{Y}$ and therefore further researches will be done in order to evaluate the potential role of these conjugates in diagnostics and therapy of metastatic breast cancer. 


\section{Acknowledgment}

This research was supported by the Ministry of Education, Science and Technological Development of the Republic of Serbia (Grant No. 172044) and by the University Goce Delcev, Faculty of Medical Sciences, Štip, Republic of North Macedonia (Grant No. 0201-165/6). Commercial Herceptin ${ }^{\circledR}$ was provided by University Clinic for Radiotherapy and Oncology, Skopje.

\section{References}

1. Ross JS, Slodkowska EA, Symmans WR, Pusztai L, Ravdin PM, Hortobagyi GN. The HER-2 receptor and breast cancer: ten years of targeted anti-HER-2 therapy and personalized medicine. Oncologist 2009; 14 (4):320-68. [CrossRef] [PubMed]

2. Fendly BM, Winget $M$, Hudziak RM, Lipari MT, Napier $M A$, Ullrich A. Characterization of murine monoclonal antibodies reactive to either the human epidermal growth factor receptor or HER2/neu gene product. Cancer Res 1990; 50(5):1550-8. [PubMed]

3. Carter $P$, Presta L, Gorman CM, Ridgway JBB, Henner D, Wong WLT, et al. Humanization of an anti-p185 ${ }^{\text {HER2 }}$ antibody for human cancer therapy. Proc Natl Acad Sci USA 1992; 89(10):4285-9. [CrossRef] [PubMed]

4. Gennari R, Menard S, Fagnoni F, Ponchio L, Scelsi M, Tagliabue $E$, et al. Pilot study of the mechanism of action of preoperative trastuzumab in patients with primary operable breast tumors overexpressing HER2. Clin Cancer Res 2004; 10(17):5650-5.

[CrossRef] [PubMed]

5. Sharkey RM, Goldenberg DM. Targeted therapy of cancer: new prospects for antibodies and immunoconjugates. CA Cancer J Clin 2006; 56(4):226-43. [CrossRef] [PubMed]

6. Tilyou SM. Targeting disease for diagnosis and treatment. J Nucl Med 1990; 31(12):15A-30A. [PubMed]

7. Hooge MNL, Kosterink JGW, Perik PJ, Nijnuis $\mathrm{H}$, Tran $\mathrm{L}$, Bart J, et al. Preclinical characterization of ${ }^{111} \mathrm{In}$ DTPA-trastuzumab. Br J Pharmacol 2004; 143(1):99106. [CrossRef] [PubMed]

8. Perik PJ, Hooge MNL, Gietema JA, Graaf WTA, Korte $M A$, Jonkman $S$, et al. Indium-111-labeled trastuzumab scintigraphy in patients with human epidermal growth factor receptor 2-positive metastatic breast cancer. J Clin Oncol 2006; 24(15):2276-82. [CrossRef] [PubMed]

9. McLarty K, Cornelissen B, Scollard DA, Done SJ, Chun K, Reilly RM. Associations between the uptake of ${ }^{111} \mathrm{In}$ DTPA-trastuzumab, HER2 density and response to trastuzumab (Herceptin) in athymic mice bearing subcutaneous human tumor xenografts. Eur J Nucl Med Mol Imaging 2009; 36(1):81-93. [CrossRef] [PubMed]

10. Chen WJ, Yen CL, Lo ST, Chen KT, Lo JM. Direct ${ }^{99 \mathrm{~m} T C}$

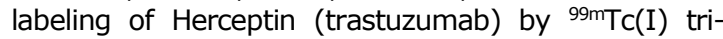
carbonyl ion. Appl Radiat Isot 2008; 66(3):340-5. [CrossRef] [PubMed]

11. Alirezapour B, Jalilian AR, Bolourinovin F, Moradkhani S. Production and quality control of $\left[{ }^{67} \mathrm{Ga}\right]-D O T A-$ trastuzumab for radioimmunoscintigraphy. Iran J Pharm Res 2013; 12(2):355-66. [PubMed]

12. Palm S, Enmon RM, Matei C, Kolbert KS, Xu S, Zanzonico PB, et al. Pharmacokinetics and biodistribution of ${ }^{86} \mathrm{Y}$-trastuzumab for ${ }^{90} \mathrm{Y}$ dosimetry in an ovarian carcinoma model: correlative microPET and MRI. J Nucl Med 2003; 44(7):1148-55. [PubMed]

13. Rasaneh S, Rajabi H, Akhlaghpoor S, Sheybani S. Radioimmunotherapy of mice bearing breast tumor with ${ }^{177}$ Lu-labeled trastuzumab. Turk J Med Sci 2012; 42(1):1292-8. [CrossRef]

14. Ray GL, Baidoo KE, Keller LMM, Albert PS, Brechbiel MW, Milenic DE. Pre-clinical assessment of ${ }^{177} \mathrm{Lu}-$ labeled trastuzumab targeting HER2 for treatment and management of cancer patients with disseminated intraperitoneal disease. Pharmaceuticals 2012; 5(1):15. [CrossRef] [PubMed]

15. Brechbiel MW. Bifunctional chelates for metal nuclides. Q J Nucl Med Mol Imaging 2008; 52(2):166-73. [PubMed]

16. Jacob S, Shirwaikar AA, Srinivasan KK, Alex J, Prabu $\mathrm{SL}$, Mahalaxmi R, et al. Stability of proteins in aqueous solution and solid state. Indian J Pharm Sci 2006; 68 (2):154-63. [CrossRef]

17. Gjorgieva Ackova D. Examination of therapeutic radiopharmaceuticals based on monoclonal antibodies and peptides [dissertation]. Skopje: Ss. Cyril and Methodius Univ.; 2015.

18. Nebija D, Noe CR, Urban E, Lachmann B. Quality control and stability studies with the monoclonal antibody, trastuzumab: Application of 1D-vs. 2D-gel electrophoresis. Int J Mol Sci 2014; 15(4):6399-411. [CrossRef] [PubMed]

19. Gjorgieva Ackova D, Smilkov K, Janevik-Ivanovska E. Formulation and characterization of "Ready to Use" 1B4M-DTPA-rituximab for Lu-177 labeling. World J Med Sci 2014; 11(4):535-40.

20. Cooper MS, Ma MT, Sunassee K, Shaw KP, Williams $\mathrm{JD}$, Paul RL, et al. Comparison of $64 \mathrm{Cu}$-complexing bifunctional chelators for radioimmunoconjugation: labeling efficiency, specific activity and in vitro/in vivo stability. Bioconjug Chem 2012; 23(5):1029-39. [CrossRef] [PubMed]

21. Beardsley DS, Spiegel JE, Jacobs MM, Handin RI, Lux SE. Platelet membrane glycoprotein IIIa contains target antigens that bind anti-platelet antibodies in immune thrombocytopenias. J Clin Invest 1984; 74 (5): 1701-7. [CrossRef] [PubMed] 
22. Wang W, Singh S, Zeng DL, King K, Nema S. Antibody structure, instability and formulations. J Pharm Sci 2007; 96(1):1-26. [CrossRef] [PubMed]

23. Chang BS, Patro SY. Freeze-drying process development for protein pharmaceuticals. In: Lyophilization of Biopharmaceuticals. Arlington: AAPS 2004; 113-38.

24. Tang XT, Pikal MJ. Design of freeze-drying processes for pharmaceuticals: Practical advice. Pharm Res 2004; 21(2):191-200. [CrossRef] [PubMed]

25. Izutsu K, Yoshioka S, Terao T. Effect of mannitol crystallinity of the stabilization of enzymes during freezedrying. Chem Pharm Bull 1994; 42(1):5-8. [CrossRef] [PubMed]

26. Nounou MM, El-khordagui L, Khallafallah N, Khalil S. Influence of different sugar cryoprotectants on the sta- bility and physico-chemical characteristics of freezedried 5-fluorouracil plurilamellar vesicles. DARU J Pharm Sci 2005; 13(4):133-42.

27. Vlasak J, Ionescu R. Fragmentation of monoclonal antibodies. MAbs 2011; 3(3):253-63. [CrossRef] [PubMed]

28. Milenic DE, Baidoo KE, Brechbiel MW. Bench to bedside: Stability studies of GMP produced trastuzumabTCMC in support of a clinical trial. Pharmaceuticals 2015; 8(3):435-54. [CrossRef] [PubMed]

29. Pabari RM, Ryan B, Ahmad W, Ramtoola Z. Physical and structural stability of the monoclonal antibody, trastuzumab (herceptin ${ }^{\circledR}$ ), intravenous solutions. Curr Pharm Biotechnol 2013; 14(2):220-5. [PubMed] 


\title{
PRIPREMA I ISPITIVANJE INTEGRITETA LIOFILIZIRANIH KITOVA TRASTUZUMAB-IMUNOKONJUGATA I HLADNO OBELEŽENIH IMUNOKONJUGATA PRIMENOM SDS-PAGE ELEKTROFOREZE
}

\author{
Marija Sterjova1,2, Predrag Džodić ${ }^{1}$, Tatjana Ruskovska1 ${ }^{1}$ Paulina Apostolova ${ }^{1}$, \\ Milan Risteski ${ }^{3}$, Emilija Janevik-Ivanovska ${ }^{1}$
}

\begin{abstract}
${ }^{1}$ Univerzitet "Goce Delčev", Fakultet medicinskih nauka, Štip, RS Makedonija
2Univerzitet u Nišu, Medicinski fakultet, Odsek za farmaciju, Niš, Srbija

${ }^{3}$ Univerzitetska klinika za radioterapiju i onkologiju, Skopje, RS Makedonija
\end{abstract}

Kontakt: Marija Sterjova

Sutjeska 43b/5, Štip, RS Makedonija

E-mail: marija.sterjova@ugd.edu.mk

Radioimunokonjugati su agensi za koje se smatra da imaju veliki potencijal u dijagnostici i lečenju različitih tipova kancera. Cilj ove studije je formulacija stabilnih liofiliziranih kitova trastuzumaba korišćenjem tri vrste bifunkcionalnih helatora, radi daljeg radioaktivnog obeležavanja. Integritet antitela u formulisanim konjugatima ispitivan je primenom natrijum dodecil sulfat poliakrilamid gel elektroforeze (SDS-PAGE).

Trastuzumab je humanizovano monoklonsko antitelo koje se koristi u terapiji agresivnog HER2 pozitivnog kancera dojke. Konjugacija trastuzumaba izvršena je korišćenjem različitih helatora: p-SCN-Bn-DTPA (1:10; 1:20; 1:50), p-SCN-Bn-DOTA (1:20), i 1B4M-DTPA $(1: 10 ; 1: 20 ; 1: 50)$. Prečišćeni imunokonjugati liofilizirani su primenom dvodnevnog protokola kako bi se dobili stabilni liofilizirani kitovi. Hladno obeležavanje neradioaktivnim izotopima $\mathrm{LuCl}_{3}$ i $\mathrm{YCl}_{3}$ izvršeno je da bi se uočile potencijalne modifikacije sekundarne strukture nakon radioaktivnog obeležavanja. SDS-PAGE elektroforeza u uslovima redukcije korišćena je za utvrđivanje čistoće i integriteta antitela pre i posle konjugacije, liofilizacije i obeležavanja.

$\mathrm{Na}$ osnovu dobijenih rezultata nije uočena degradacija ispitivanog antitela. Trastuzumab-konjugati i hladno obeležene formulacije migriraju u dve trake ( $\sim 50 \mathrm{kDa}$ i $\sim 25 \mathrm{kDa})$, na isti način kao IgG1 antitela i nemodifikovani trastuzumab.

Acta Medica Medianae 2019;58(3):15-23.

Ključne reči: bifunkcionalni helatori, konjugati, elektroforeza, trastuzumab 